GRZEGORZ KARWASZ

ORCID 0000-0001-7090-3123

Uniwersytet Mikołaja Kopernika

$w$ Toruniu

\title{
STRATEGIE DYDAKTYKI KOGNITYWISTYCZNEJ: HYPER-KONSTRUKTYWIZM I NEO-REALIZM. PODSTAWY TEORETYCZNE
}

\begin{abstract}
AвSTRACT. Karwasz Grzegorz, Strategie dydaktyki kognitywistycznej: hyper-konstruktywizm i neo-realizm. Podstawy teoretyczne [Strategies of Cognitivist Pedagogy: Hyper-Constructivism and Neo-Realism. Theoretical Foundations]. Studia Edukacyjne nr 60, 2021, Poznań 2021, pp. 113-134. Adam Mickiewicz University Press. ISSN 1233-6688. DOI: 10.14746/se.2021.60.7

While the term "cognitivistic pedagogy" appeared already in Polish literature, "cognitivistic didactics" is addressed mainly by foreign authors. We define principles and methods of innovative didactics based on constructivistic and cognitivistic theories. The two main paradigms of such didactics consist in constructing the knowledge (and competences) of pupils (listeners, students) in an interactive narration and in using real didactic objects, preferably pulled out of a pocket. We call these concepts hyper-constructivism and neo-realism.
\end{abstract}

Key words: cognitivism, constructivism, interactive didactics

\section{Potrzeba nowej dydaktyki}

Pojawienie się Internetu zaledwie dwadzieścia lat temu ${ }^{1}$ zmieniło zasadniczo dostęp do wiedzy: już nie tygodniowe poszukiwania w setkach tomów abstraktów na półkach w bibliotekach, ale ułamek sekundy - o ile udało się w Google’u napisać właściwy wyraz, a autor publikacji zadbał o właściwe jej pozycjonowanie. Problemem staje się nie uzyskanie informacji, ale pozbycie

${ }^{1}$ W 1999 roku zaledwie połowa nauczycieli i szkół w USA dysponowała dostępem do Internetu (B. Smerdon i in., Teachers' Tools for the 21st Century: A Report on Teachers' Use of Technology, National Center for Education Statistics, September 2000, s. 14). Przypomnijmy, że w Polsce w 1996 roku toczyła się publiczna debata na temat odpłatności dostępu do Internetu dla wyższych uczelni; Internet nie był dostępny dla osób prywatnych. 
się tej niechcianej. Jeszcze większym problemem staje się właściwa i sprawna ocena, przesiewanie i porządkowanie informacji w umyśle człowieka ${ }^{2}$. Już nie działania w świecie materialnym - produktów rolniczych, rzemieślniczych, czy przemysłowych - stanowią pożądaną umiejętność, ale wytwarzanie, magazynowanie, sprzedawanie (i utylizacja) zasobów komputerowych, czyli wirtualnych. Giganci „przemysłu” informacyjnego zaczynają wyprzedzać gigantów przemysłu samochodowego, stoczniowego, a nawet elektronicznego. Jak pisze Andrzej Ćwikliński:

Przyszło nam żyć na przełomie dwóch etapów cywilizacyjnego rozwoju ludzkości: przemijającego, związanego z erą przemysłową, oraz informacyjnego, którego burzliwy rozwój możemy obserwować na przełomie wieków. Stąd pojawia się potrzeba podjęcia nowego wyzwania, którym jest przygotowanie ludzi do radzenia sobie w nowej rzeczywistości, tj. w społeczeństwie wiedzy³.

Ta wszech-dostępność informacji pozwala też na zupełnie nową dydaktykę - skuteczną, szybką, trwałą i przyjemną (czyli taką, o jakiej pisał Komeński $\left.{ }^{4}\right)$. Wszystkie informacje możemy znaleźć w Internecie - eksperymenty fizyczne, teksty lektur i ich streszczenia, rozwiązania zadań z algebry dla studentów i tym podobne. Wszystko zobrazowane jest nieprzeliczalnymi zasobami multimediów - różnego rodzaju, w różnych formach, różnego przeznaczenia ${ }^{5}$. Wydaje się, że nauczyciel staje się niepotrzebny. Wydaje się, bo to właśnie nauczyciel w pierwszej kolejności powinien dostosować sposoby nauczania do zmieniającej się sytuacji nie tylko percepcji ucznia, ale całości zmian kulturowych w środowisku otaczającym szkołę. Zadaniem nauczyciela staje się nie sam przekaz wiedzy, ale kierowanie procesem zdobywania wiedzy przez uczniów - procesem w dużej mierze autonomicznym. Stanisław Dylak zwraca uwagę na zasadniczą trudność, jaką ta zmiana roli sprawia nauczycielom:

${ }^{2}$ Jan Komeński w Wielkiej dydaktyce tak pisał o konieczności przesiewania wiedzy: „Ułatwimy przeto zadanie szkołom, jeśli skracać będziemy treść nauki, co nastąpi, jeśli pomijać będziemy: I. to, co bezużyteczne, II. to, co obce, III. to, co jest zbyt drobiazgowe"; J.A. Komenský, Wielka dydaktyka Jana Amosa Komeńskiego, przekł. H. Wernic, Warszawa 1883, s. 143.

3 A. Ćwikliński, Zmiany w polskiej edukacji w okresie globalizacji, integracji i transformacji systemowej, Poznań 2005, s. 95.

4 „1. Zamierzamy teraz powyższe rozproszone uwagi, tyczące się nauczania zgodnego z wymaganiami dydaktyki, nauk, języków, moralności i pobożności, razem przestawić dla łatwiejszego ich zastosowania. Mówię z naciskiem według wymagania dydaktyki, t. z. łatwo, gruntownie i szybko"; J.A. Komenský, Wielka dydaktyka, s. 143.

${ }^{5}$ Zob. np. G. Karwasz, Czy media $w$ dydaktyce sa potrzebne? [w]: Media w edukacji, kulturze i zmianie społecznej - odniesienia kognitywne, Księga jubileuszowa poświęcona profesorowi Bronisławowi Siemienieckiemu w 60. rocznicę urodzin, red. S. Juszczyk, Toruń 2010, s. 167-172. 
Nauczyciel zawsze był mandatariuszem wiedzy dla uczniów. I to stało się obecnie bodaj największym obciążaniem tej profesji. Przekonanie o przekazywaniu wiedzy jako głównym zadaniu nauczyciela nie przystaje już do dzisiejszych realiów, w których problemem nie jest brak informacji, tylko jej nadmiar. W takiej sytuacji przekazywanie wiedzy przestało być najważniejszym zadaniem nauczyciela. Co więcej - przekazywanie wiedzy jest sprzeczne z konstruktywistyczną interpretacją samej wiedzy. Ta bowiem - w ujęciu konstruktywistycznym rozumiana jako system twierdzeń o rzeczywistości zbudowany $\mathrm{w}$ toku własnej aktywności poznawczej z uwzględnieniem już posiadanej wiedzy, sądów, przekonań, intuicji i emocji - trudna jest do przekazania. Podobnie jak doświadczenia osobiste, których nie można przekazać komuś, zaś można tylko o nich opowiadać i organizować sytuacje inicjujące określone doświadczenia ${ }^{6}$.

\section{Cytując ponownie Andrzeja Ćwiklińskiego:}

Konwencjonalne procesy uczenia się nie odpowiadają potrzebom nowej cywilizacji. Informacja stała się warunkiem naszego przetrwania, ponieważ umożliwia konieczną wymianę między nami a naszym środowiskiem ${ }^{7}$.

Natłok informacji stwarza podstawowe problemy z jej uporządkowaniem. Łatwo zebrana informacja trafia w ogromnych ilościach również do podręczników szkolnych, mnożą się tabele, „bryki”, poradniki, kompendia, atlasy i tym podobne. Podręczniki szkolne, szczególnie w Polsce, są przeładowane drobiazgowymi informacjami nie stanowiącymi całościowej konstrukcji (ryc. 1a). Łatwość dostępu do informacji nie przekłada się na wyniki maturalne ani na wiedzę studentów na poziomie szkoły średniej. Nie tylko w dziedzinie fizyki, ale również historii (nawet lokalnej), geografii, biologii studenci mają braki obejmujące większość materiału szkolnego. Wymownym świadectwem jest zarówno procent zdawalności matury, z matematyki na poziomie 30\%, jak i szczegółowe jej wyniki, na przykład z fizyki ${ }^{8}$, przypominające rozkład Poissona, czyli zdarzeń rzadkich (ryc. 1b).

Zadaniem dydaktyki staje się więc formułowanie podstawy programowej, jednak nie tej formalnej, ministerialnej, ale minimum wiedzy, jaką absolwent liceum winien sprawnie operować. W dziedzinie fizyki jest to prawo swobodnego spadku Galileusza, pojęcie energii i równoważność Einsteina (zresztą $E=m c^{2}$ było tytułem polskiego filmu). Dysponując tą podstawą, można na niej budować dalszą operatywna naukowo i praktycznie wiedzę. Naukowo aby zrozumieć, że w spadku swobodnym następuje zamiana energii potencjalnej w kinetyczną, a praktycznie - aby zaakceptować energetykę jądrową, w której korzystamy z równoważności masy i energii.

${ }^{6}$ S. Dylak, „Nasze szkolne credo...", [w:] Strategia kształcenia wyprzedzajacego, red. S. Dylak, Poznań, 2013, s. 7.

7 A. Ćwikliński, Zmiany w polskiej edukacji, s. 109.

${ }^{8}$ J. Brojan, S. Sawicki, S. Sapanowski, Sprawozdanie z egzaminu maturalnego 2014. Fizyka i astronomia, Warszawa 2014, s. 5. 
Tabela. Hipsometria kontynentów: powierzchnia kontynentów w przedziałach wysokości (w \%) oraz średnia wysokość kontynentów (w m n.p.m.)

\begin{tabular}{|l|c|c|c|c|c|c|c|}
\hline $\begin{array}{l}\text { Wysokość } \\
\text { wm n.p.m. }\end{array}$ & Europa & Azja & Afryka & $\begin{array}{c}\text { Ameryka } \\
\text { Północna }\end{array}$ & $\begin{array}{c}\text { Ameryka } \\
\text { Południowa }\end{array}$ & $\begin{array}{c}\text { Australia } \\
\text { i Oceania }\end{array}$ & Antarktyda \\
\hline powyżej 5000 & 0,0 & 2,6 & 0,0 & 0,5 & 1,1 & 0,0 & 0,1 \\
\hline $3000-5000$ & 0,1 & 3,9 & 0,2 & 0,1 & 3,9 & 0,2 & 2,5 \\
\hline $2000-3000$ & 0,6 & 6,0 & 1,5 & 10,1 & 3,4 & 0,7 & 56,9 \\
\hline $1000-2000$ & 4,4 & 17,5 & 20,2 & 16,5 & 6,2 & 2,4 & 28,7 \\
\hline $500-1000$ & 10,9 & 21,2 & 28,6 & 17,4 & 16,9 & 13,0 & 5,2 \\
\hline $300-500$ & 10,0 & 15,6 & 27,0 & 22,6 & 19,5 & 29,5 & 0,2 \\
\hline $0-300$ & 72,6 & 32,1 & 22,4 & 32,8 & 49,0 & 54,0 & 6,4 \\
\hline poniżej 0 & 1,4 & 1,1 & 0,1 & 0,0 & 0,0 & 0,2 & 0,0 \\
\hline $\begin{array}{l}\text { Średnia } \\
\text { wysokość }\end{array}$ & 292 & 987 & 657 & 781 & 655 & 330 & 2030 \\
\hline w m n.p.m. & & & & & & & \\
\hline
\end{tabular}



Ryc. 1a. Przykład z podręcznika geografii do 8 klasy szkoły podstawowej dotyczący hipsometrii kontynentów. Szczegółowość danych zawartych w tabeli nie pozwala na ich porządkującą analizę. Znacznie czytelniejszy byłby wykres słupkowy lub po prostu mapa fizyczna kontynentów

Ryc. 1b. Rozkład wyników matury z fizyki w roku 2014 - poziom podstawowy przypominający rozkład Poissona, czyli rozkład zdarzeń mało prawdopodobnych: zdanie matury z fizyki to spory „łut szczęścia”. Rozkład wyników na poziomie rozszerzonym jest gaussowski, czyli normalny. Innymi słowy, nauczanie fizyki jest adresowane do wybrańców,

a nie do wszystkich. A to już poważnie narusza przydatność przedmiotu jako ogólnie dostępnego

(źródło: J. Brojan, S. Sawicki, S. Sapanowski, Sprawozdanie z egzaminu maturalnego 2014. Fizyka $i$ astronomia, Centralna Komisja Egzaminacyjna, Warszawa 2014)

Wszechobecność informacji, i to nie tylko w Internecie, ale również w telewizjach dydaktycznych, dyskusjach rówieśników na podwórku i tym po- 
dobnych, stwarza możliwość nowej dydaktyki, w której nie musimy nawet korzystać z Internetu: wystarczy wiedza w grupie klasowej (wykładowej, seminaryjnej). Grupa szkolna, pozornie samodzielnie (ale pod ścisłą i rozumną kontrolą nauczyciela), staje się podmiotem konstruującym własną wiedzę. Metodologię tę nazywamy nad-konstruktywizmem.

\section{Hyper-konstruktywizm}

Za praźródło wyjściowe do tej nowej dydaktyki można przyjąć konstruktywizm - i to nawet $\mathrm{w}$ ujęciu społecznym ${ }^{9}$ : wiedza jest uzgadniana $\mathrm{w}$ określonej grupie społecznej. Ale w odróżnieniu od ujęcia Bergera i Luckmanna, nie dopuszczamy relatywizmu wyniku: prawo Newtona, do którego musi doprowadzić proces uzgadniania w grupie klasowej/studenckiej, winno mieć, ostatecznie, właściwe sformułowanie.

Celem działania dydaktycznego jest wytworzenie w umyśle ucznia określonej koncepcji (dokonania kategoryzacji, jak to nazywa Jerome Bruner): zrozumienia pojęcia, procesu, równania, zjawiska. Jak podkreśla Bruner ze współpracownikami ${ }^{10}$, kategoryzacja umożliwia dokonanie uproszczenia złożonego środowiska ${ }^{11}$. Kategoryzacja zmniejsza również konieczność stałego, szczegółowego uczenia się: raz skonstruowana koncepcja staje się bazą do kolejnego kroku poznawczego.

W koncepcji hyper-konstruktywistycznej wiedzę konstruujemy w klasie, w swobodnej (pozornie) dyskusji, w której uczniowie/studenci swobodnie formułują własne zdanie, zapisują je, swobodnie i demokratycznie (uczestniczą wszyscy) dyskutują, a później, po zakończonej dyskusji - oceniają sformułowane opinie i protokołują wnioski (nieco podobnie, jak w klasycznej burzy mózgów). Istotny w procesie uzgadniania wiedzy jest udział wszystkich członków powołanej ad hoc społeczności - bez przypisywania a priori podziału ról („a Waldek to się zna na technice”). Pedagogiczny cel - przyzwyczajenie do samodzielności (i odpowiedzialności ${ }^{12}$ ) - jest dla wytworzenia kompetencji społecznych znacznie ważniejszy, aniżeli szczątkowa wiedza, jak to przysłowiowe prawo Newtona. Andrzej Ćwikliński pisze:

\footnotetext{
${ }^{9}$ P.L. Berger, T. Luckmann, Społeczne tworzenie rzeczywistości, przekł. J. Niżnik, Warszawa 2010.

${ }^{10}$ J.S. Bruner, J.J. Goodnow, G.A. Austin, A Study of Thinking, New Brunswick - New York 1986, s. 12.

${ }_{11}$ „By categorizing as equivalent discriminably different events, the organism reduces the complexity of its environment" (Tamże).

${ }_{12}$ Zob. G. Karwasz, Między neorealizmem a hyper-konstryktywizmem - strategie dydaktyczne dla XXI wieku, [w]: Awangarda w szkolnej i pozaszkolnej edukacji, Problemy Wczesnej Edukacji, 2011, 3(15), s. 8-30.
} 
Dzisiaj coraz częściej przyjmuje się, iż samodzielność jest właściwością wykształconą podczas czynności działań poznawczych, a samodzielność w myśleniu i działaniu człowieka charakteryzuje się określonym stopniem niezależności od warunków zewnętrznych i wewnętrznych oraz umiejętnością wychodzenia poza znane schematy myślenia i działania ${ }^{13}$.

W odróżnieniu jednak od konstruktywizmu społecznego, w proponowanej metodologii wynik nie jest uzgodnieniem zdań, ale prawem Newtona, które należało sformułować. A właściwie, jak precyzujemy to dalej, kognitywną percepcją tego prawa: w umyśle każdego ucznia określona konstrukcja, na którym to prawo się opiera, będzie nieco inna - nie tylko w zależności od różnych predyspozycji (wzrokowych, słuchowych, manualnych; praktycznych, abstrakcyjnych itd.), ale również w funkcji poprzedniej wiedzy (szkolnej, pozaszkolnej) i wiadomości skorelowanych $z$ innych dziedzin. Ilość indywidualnych uwarunkowań decydujących o końcowej konstrukcji pojęciowej jest ogromna ${ }^{14}$.

W hyper-konstruktywistycznej dydaktyce prowadzeniem dyskusji musi zajmować się nauczyciel, wiedząc jaka droga (a właściwie jakie różne, alternatywne drogi) prowadzi do wyniku. A droga ta obrazowo stanowi ścieżkę po głazach ułożonych w odległości kroku, ale pieczołowicie, jak miny na pustyni, przysypanych piaskiem: nauczyciel zna ich rozkład, ale uczeń musi przejść ścieżkę krok po kroku ${ }^{15}$.

Nauczyciel/wykładowca/showman na pokazie/wykładzie/warsztatach w klasie szkolnej/sali teatralnej/na festiwalu nauki prowadzi dyskusję krok po kroku, jakby według klasycznej zasady stopniowania trudności czy systematyczności ${ }^{16}$. Każdy krok kończy się osiągniętym consensusem. W odróżnieniu od klasycznych zasad, a zgodnie z zasadą naczelną no-student-left-behind ${ }^{17}$, wszyscy uczniowie muszą być przekonani o tym consensusie. Jakakolwiek wątpliwość któregokolwiek ucznia oznacza, że przeprowadzone rozumowanie nie było wyczerpujące - nie obejmowało możliwych „rozgałęzień" ścieżki poznawczej i/lub nie było dostatecznie usieciowane poprzez możliwe skoja-

13 A. Ćwikliński, Zmiany w polskiej edukacji, s. 111.

14 Ta ogromna liczba uwarunkowań poprawnej wiedzy czyni metody konstruktywistyczne niezbyt popularne wśród nauczycieli, również w tak rozwiniętych edukacyjnie krajach, jak Wielka Brytania czy Republika Korei (praktyczne doświadczenia dydaktyczne autora).

${ }^{15}$ W literaturze dydaktyki kognitywistycznej pojawia się również pojęcie „budowania mostów”. Tak piszą Gagnon i Collay: „Przed rozpoczęciem jakiejkolwiek 'nowej' nauki, nauczyciel musi zaprosić studentów do przejrzenia ich poprzedniej wiedzy, która służy jako 'stopa' albo fundament mostu pomiędzy tym, co studenci już wiedzą, a nowym nauczaniem, które zbudują" [tłumaczenie - G.K.]; G.W. Gagnon Jr., M. Collay, Constructivistic Learning Design. Key Questions for Teaching to Standards, California 2006, s. 86.

16 Zob. np. F. Bereźnicki, Dydaktyka kształcenia ogólnego, Kraków 2007.

17 Zob. G. Karwasz, A. Karbowski, No student left behind - recepta konstruktywistyczna - implementacje i analizy porównawcze w fizyce, [w:] Różnice, edukacja, inkluzja, red. A. Komorowska, Gdańsk 2015, s. 103-114. 
rzenia i/lub nie pokazało zastosowań praktycznych i wiedzy interdyscyplinarnej i/lub użyty język był niezrozumiały - hermetyczny i specjalistyczny ${ }^{18}$.

Obrazowo, wybór kierunku rozumowania i osiągane consensusy częściowe przypominają kroczenie przez jezioro po palach ukrytych tuż pod taflą wody: należy stabilnie stanąć na dwóch nogach na wybranym palu, po czym dokładnie sprawdzić, gdzie postawić kolejny krok $^{19}$. A przy tym ścieżka pali musi prowadzić do określonego punktu - celu lekcji (faktu, pojęcia, prawa, zjawiska) po drugiej stronie jeziora ${ }^{20}$.

Rozumowanie razem z grupą stanowi istotę drugiej, obok konstruktywizmu, zasady nowej dydaktyki, a mianowicie kognitywizmu. Nauczanie prawa Newtona nie ma przebiegać zgodnie z tym, co wymyślili fizycy teoretycy, ale według obrazu, jaki powstaje w umysłach uczniów. To nie Newton ma rozumieć swoje prawa, ale nastolatek w XXI wieku, z jego własnymi uwarunkowaniami, które składają się na specyficzne środowisko kulturowe: przypisane do momentu historycznego, miejsca geograficznego, statusu ekonomicznego, dostępu do wiedzy i tak dalej ${ }^{21}$.

Nauczyciela nie interesuje prawo Newtona samo w sobie, ale przedstawienie, czyli reprezentacja tego prawa w umysłach uczniów ${ }^{22}$ : to oni muszą to prawo rozumieć i stosować. Kopnięcie ciężkiej piłki lekarskiej może się skończyć zwichnięciem kostki; zjeżdżanie z górki na rowerze bez hamowania „rozpędza” rower dokładnie do tej samej szybkości, do jakiej rozpędza się samochód na tej samej górce - można poważnie rozbić głowę. Droga hamowania nie zależy od stanu hamulców, ale od nawierzchni drogi. Wprowadzenie praw Newtona nie tylko do szkolnej wiedzy, ale wręcz do podświadomości ucznia dostarcza tych kompetencji, które będą przydatne w dorosłym życiu. Jest to znacznie dalej posunięte stwierdzenie niż klasyczna zasada „zastosowania wiedzy w praktyce": jest to kompetencja społeczna ${ }^{23}$.

Należy podkreślić subiektywność wytwarzanych indywidualnych kategorii pojęciowych. Jak pisze Anita Pacholik-Żuromska, charakteryzując kognitywizm w ujęciu Jerry'ego Fodora:

${ }^{18}$ G. Karwasz, Nauczanie fizyki - trudności matematyczne czy nieumiejętność komunikacji? Kognitywistyka i Media w Edukacji, 2013, 1, s. 107-114.

19 Ta sama koncepcja, budowania wiedzy na palach-fundamentach pojawiła się, bodajże, $\mathrm{u}$ Karla Poppera, ale autor $\mathrm{z}$ niej nie korzystał: obie przedstawione $\mathrm{w}$ tej pracy metodologie, hyper-konstruktywizm i neo-realizm pojawiły się jako ewolucja praktycznych, autorskich implementacji dydaktyki interaktywnej.

${ }^{20}$ Zob. ilustrację w: G. Karwasz, Między neorealizmem a hyper-konstryktywizmem, s. 8-30.

${ }^{21}$ Zob. B. Siemieniecki, Pedagogika kognitywistyczna. Studium teoretyczne, Kraków 2013.

22 Zob. J. Kruk, G. Karwasz, Reprezentacja, przyczynowość i badania eksperymentalne jako znaczace punkty "mapy poznawczej” dydaktyki ogólnej, Forum Oświatowe, 2005, 2(33), s. 97-111.

${ }^{23}$ G. Karwasz, A. Karbowski, Hyper-konstruktywizm w nauczaniu fizyki. Tożsamość indywidualna i kompetencje społeczne, Acta Universitatis Nicolai Copernici. Pedagogika, 2016, XXXII, Nauki Humanistyczno-Społeczne, 435, s. 177-202. 
Są one [nastawienia sądzeniowe] relacjami pomiędzy podmiotem a treścią danego sądu. Inaczej mówiąc, podmiot przyjmuje wobec konkretnych sądów nastawienia, wyrażające się w jakiejś psychologicznej modalności, np. przekonaniu czy wierzeniu. Treść tego sądu ma charakter reprezentacji mentalnej, której najmniejszy składnik stanowią pojęcia ${ }^{24}$.

Celem dydaktyki hyper-konstruktywistycznej nie jest prosty przekaz wiedzy, ale wytworzenie pojęć w umyśle ucznia, w założeniu obiektywnych, w praktyce zawsze nieco subiektywnych.

Reasumując, nauczyciel obserwuje twarze uczniów i wskutek wyniku tej obserwacji prowadzi, przerywa, lub zmienia tok rozumowania. Kognitywizm z całą jego złożonością jest więc równie ważny w wykształceniu nauczyciela, jak podstawy fizyki. Lee Shulman nazywa tę pozaprzedmiotową wiedzę PCK - „Pedagogical Contents Knowledge” ${ }^{25}$, stanowiący cały zespół doświadczenia i zachowań, które odróżniają dwóch znawców tematu - czystego naukowca i nauczyciela ${ }^{26}$.

Celem nowej dydaktyki jest więc konstruowanie w umyśle ucznia racjonalnego obrazu rzeczywistości (przyrodniczej, technicznej, humanistycznej). Co więcej, możliwe jest interaktywne konstruowanie zagadnienia z grupą uczniów (słuchaczy na wykładzie uniwersytetu dziecięcego, studentów na seminarium), korzystając jedynie $\mathrm{z}$ ich wiedzy. Poglądowość zostaje zastąpiona przez indywidualne wiadomości uczniów: to ich odpowiedzi stają się „naocznością".

Podkreślamy, że w odróżnieniu od konstruktywizmu społecznego, tworzony interaktywnie obraz rzeczywistości nie jest jednak czystym wynikiem uzgodnień, ale założoną programowo treścią; proces uzgadniania przypomina konstruktywizm, ale jest to proces ściśle prowadzony przez nauczyciela. Zasobami wyjściowymi nie jest podręcznik, nie jest „wiedza potoczna”, ale wiadomości zebrane spontanicznie przez pojedynczych uczniów w ich samodzielnym uczeniu się, głównie pozaszkolnym. Zadaniem nauczyciela jest selekcjonowanie tych odpowiedzi, które są właściwe do konstruowania kolejnego kroku ścieżki poznawczej ${ }^{27}$.

${ }^{24}$ A. Pacholik-Żuromska, Ewolucja jezzyka myśli, Diametros, 2012, 34, s. 79-91.

${ }^{25}$ L.M. Shulman, Knowledge and teaching: Foundations of the new reform, Harvard Educational Review, 1987, 57(1), s. 1-22.

${ }^{26}$ Piero Crispiani wymogi pedagogiczne definiuje w sposób następujący: „Permanentna refleksja pedagogiczna jest niezbędna dla konstruowania systematycznej i teoretycznie uargumentowanej wizji działań dydaktycznych, $w$ ich wielorakich realizacjach; refleksja ta umożliwia formułowanie definicji i poszukiwanie dla nich konsensusu, nawet jeśli byłby on ograniczony" [tłumaczenie - G.K.]; P. Crispiani, Dydaktyka, edukacja, styl. Dydaktyka kognitywistyczna jako styl, przekł. G. Karwasz, Cognitive Science - New Media - Education, 2017, 3, s. 27.

${ }^{27}$ Nie piszemy selekcjonowanie odpowiedzi „poprawnych", bo dla stymulowania myślenia wszystkie odpowiedzi są przydatne, nawet te niewłaściwe. Nie nazywamy też ich „błęd- 
Bazą poznawczą nie jest „średnia” z wiedzy uczniów, ale takie stwierdzenia indywidualne, które prowadza do wyznaczonego przez nauczyciela celu.

Nie jest to metoda majeutyczna, bo celem nie jest wykazanie wyższości operacyjnej nauczyciela nad uczniem, ale zachęta do samodzielnego poszukiwania wiadomości i ich oceny: uczniowie sami stawiają pytania i dyskutują odpowiedzi, a nauczyciel w razie potrzeby jedynie reformułuje pytania tak, aby prowadziły do właściwego celu. Umiejętność formułowania pytań wychodzi nawet poza wytyczne UE - inquiry-based-teaching.

Co więcej, jak wskazują Kirschner i współpracownicy ${ }^{28}$, pozostawianie uczniom swobody w konstruowaniu wiedzy, dając jedynie minimalne wskazówki, nie przynosi dobrych wyników dydaktycznych. Dlatego, proponowana nowa dydaktyka, ale stosowana blisko 20 lat w różnych realiach, również za granicą ${ }^{29}$, wykracza więc poza tradycyjny konstruktywizm, choć z niego się wywodzi. Nazywamy tę metodę nad-konstruktywizmem, czyli hyper-konstruktywizmem ${ }^{30}$.

Celem metody hyper-konstruktywistycznej jest nie tylko aktywne pozyskanie wiadomości przez uczniów, ale przede wszystkim dostarczenie minimum wiedzy - trwałej i operatywnej. Służą temu interdyscyplinarność i usieciowanie wiadomości. Niewielu dorosłych pamięta wielkość powierzchni Polski lub Francji. Ale warto wiedzieć, na przykład przez rozpoczęciem wyprawy na Moskwę, o ile Rosja jest większa od Francji. Warto wiedzieć, przed rozpoczęciem dysput ekonomicznych, jaki kraj w Europie ma najwięcej mieszkańców, a z jakimi graniczy Polska. Służą temu mapy, zestawienia, porównania, analogie, odnośniki historyczne i tym podobne. Mózg człowieka w racjonalnym działaniu dla zachowania własnej operatywności usuwa wiedzę niczemu nie służącą. A zatem, zdobycze kognitywizmu stają się bazą nowej dydaktyki.

nymi", ale „poprawnymi, ale „spróbujmy jeszcze raz”, przez szacunek dla indywidualności ucznia. Błąd, jak pisze Jean-Pierre Astolfi, jest ważnym elementem nauczania - na nim uczy się nie tylko uczeń, ale przede wszystkim nauczyciel; J.-P. Astolfi, L'erreur, un outil pour enseigner. Pratiques et enjeux pédagogiques, Montrouge 2012.

${ }_{28}$ P.A. Kirschner, J. Sweller, R.E. Clark, Why Mimimal Guidance During Instruction Does Not Work: An Analysis of the Failure of Cnstructivistic, Discovery, Problem-Bases, Experiential, and Inquiry-Based Teaching, Educational Psychologists, 2006, 41(2), s. 75-86.

${ }^{29}$ G. Karwasz, Didattica cognitivista come ricetta in fisica, [w]: Le vie della pedagogia. Tra linguagi, ambiente e tecnologie, a cura di P. Crispiani e S. Pellegrini, Macerata 2016, s. 211-234.

${ }^{30}$ Konstruowanie w usieciowanych kontekstach staje się też wytyczną UE. W opracowaniu dotyczącym nauczania przedmiotów ścisłych (Hazelkorn) stwierdza się, że sukces nauczania leży w nabywaniu kompetencji kluczowych: umiejętności współpracy, słuchania cudzych idei, myślenia krytycznego, zdolności twórczych, podejmowania inicjatyw i rozwiązywania problemów; E. Hazelkorn (chair), Science Education for Responsible Citizenship, Report to the European Commission of the Expert Group on Science Education, Luxembourg 2015. 


\section{Neo-realizm}

Jeszcze przed nastaniem ery komputerów, w latach 60. XX wieku w USA rozpoczął się proces upowszechniania dostępu do wiedzy - w postaci centrów interaktywnych nauki. Pierwowzorem jest „Eksporatorium” w San Francisco ${ }^{31}$. Proces był częścią szerzej pojętej demokratyzacji, a jednocześnie "post-produktem" ogromnych nakładów ponoszonych na badania naukowe (bomba jądrowa, lot na Księżyc, era tranzystorów itd.). Zaistniało zapotrzebowanie na uczynienie wiedzy „na wyciągnięcie ręki”. I nie jest to bynajmniej tylko „Eksploratorium", ale regionalne (co sto kilometrów - Chicago, Ann Arbour, Kalamazoo, Detroit) centra, w których miejscowe społeczności uzbierały eksponaty paranaukowe (lub choćby „zabytki” techniczne, jak pierwsze pralki i lodówki), aby stworzyć lokalny ośrodek agregacji kulturowej oraz grupowej, pozaszkolnej dydaktyki, opartej na realnych, "namacalnych” eksponatach.

Programy szkolne pozostały jednak "hermetyczne” na te nowe rozwiązania dydaktyczne. W szkołach nadal pokazywano żelazne, zazwyczaj zardzewiałe, wózki do praw Newtona i podobnie zardzewiałe ciężarki. Bardziej skomplikowane pomoce naukowe w wielu szkołach (nie tylko w Polsce) do tej pory drzemią $\mathrm{w}$ pudełkach $\mathrm{z}$ szarej tektury, nie zostawszy nigdy włączone $\mathrm{w}$ proces dydaktyczny. Problemem jest niedostosowanie tych pomocy do szybkiej i "podręcznej” dydaktyki.

Jednym $\mathrm{z}$ rozwiązań, stworzonym na Uniwersytecie $\mathrm{w}$ Trydencie we Włoszech na początku lat 90. XX wieku, są interaktywne wystawy zatytułowane „Fizyka zabawek" ${ }^{22}$. Pierwsze tego typu w Polsce miały miejsce w Warszawie, Słupsku i Białymstoku ${ }^{33}$. Fascynacja tą formą dydaktyki wynika z możności „własnoręcznego" eksperymentowania. Widzom proponujemy: „prosimy dotykać eksponaty". Możliwość przeprowadzenia samodzielnego doświadczenia jest dydaktycznie dużo efektywniejsza niż skomplikowane wyjaśnienia. Największą zaletą "dotykalnych” eksponatów jest możliwość wielokrotnego eksperymentowania, a przez to samodzielnego odkrywania.

Sukces realnych eksponatów z „Fizyki zabawek”, który przerodził się w ciągu kolejnego dziesięciolecia w liczne centra nauki w całej Polsce, wynikał również z dostępności opisów doświadczeń, natychmiast umieszczonych $\mathrm{w}$ przestrzeni internetowej. A jednocześnie, wirtualizacja przekazu informacji, a w ostatnich latach również wirtualizacja komunikacji interper-

${ }^{31}$ Zob. np. G. Karwasz, J. Kruk, Idee i realizacje dydaktyki interaktywnej. Wystawy, muzea i centra nauki, Toruń 2012.

${ }^{32} \mathrm{~V}$. Zanetti i in., I giocattoli e la scienza - schede per una diversa didattica della fisica, „La fisica nella scuola" (A.I.F.) quaderno n.4 - ottobre/dicembre 1993.

${ }_{33}$ G. Karwasz, Czy świat kręci się w prawo? Fizyka i zabawki, XXXV Zjazd Fizyków Polskich, 20.09.1999 Białystok, Postępy Fizyki, 2000, 51, Zeszyt dodatkowy, s. 97. 
sonalnej ${ }^{34}$ czyni wręcz patologiczną chęć dotykania realnych przedmiotów, o czym dobrze wiedzą oprowadzający po centrach nauki: spora część eksponatów nie wytrzymuje tej żądzy "zabawy”.

W kolejnych latach proste eksponaty doświadczalne i ścieżki z nich zbudowane zostały wykorzystane $\mathrm{w}$ wielu różnorodnych formach dydaktycznych. Oczywiście, odwołanie się do rzeczywistości nie jest pomysłem nowym, a raczej powtórzonym (stąd neo-realizm). Komeński pisał:

Uczą w szkołach języków przed realiami; albowiem zajmują umysły przez kilka lat studytami językowymi i dopiero potym Bóg wie kiedy wprowadzają ich do realnych studyjów matematyki, fizyki i t. d. A przecież rzeczy stanowią rzeczywistość, a wyrazy przypadkowość: rzeczy są jakby ciałem, wyrazy jakoby odzieżą; rzeczy - jądrem, wyrazy - łupinką i osłonką. Rzeczy i wyrazów należy tedy jednocześnie udzielać umysłowi ludzkiemu; przedewszystkim rzeczy, ponieważ stanowią one przedmiot tak poznania, jak i mowy ${ }^{35}$.

Neo-realizm nie dotyczy tylko doświadczeń fizycznych. Eksponatem w nauczaniu matematyki może być równie dobrze stożkowy kieliszek do wina, jak też internetowa kopia egipskiego papirusu z XV wieku p.n.e., z rysunkiem ściętej piramidy. Ważne, aby uczeń budował skojarzenia na realnie istniejących obiektach.

\section{Trudności i zagrożenia}

Oczywiście, obie strategie - hyper-konstruktywizm i neo-realizm wymagają znacznego doświadczenia dydaktycznego. Ilustracja zagadnień za pomocą doświadczeń „wyciąganych z kieszeni” - w biologii, fizyce, chemii wymaga obycia $\mathrm{z}$ tymi eksponatami: umiejętności szybkiego przeprowadzenia pokazu, wyjaśnienia wyników, a w razie trudności z wykonaniem - wyjaśnienia powodów innego wyniku niż oczekiwany.

Również metoda hyper-konstruktywistyczna jest niezwykle trudna dla prowadzącego - wymaga stałej uwagi pedagogicznej (to reakcje uczniów określają dalszy tok narracji - trudniejszy lub bardziej zabawny) oraz niezwykle szerokiej, interdyscyplinarnej wiedzy merytorycznej. Nauczyciel nie może na żadne pytanie odpowiedzieć: „Nie! Nie masz racji!” ale, pozornie akceptując błędną odpowiedź, musi tak pokierować samodzielnym rozumowaniem ucznia, aby ten zdał sobie sprawę z błędu.

${ }^{34}$ D. Siemieniecka, G. Karwasz, Internetowa tożsamość - czyli o kreowaniu własnego ID, [w]: Oblicza internetu. Sieciowe dyskursy. (Roz)poznawanie cyfrowego świata, red. M. Sokołowski, Elbląg 2014, s. 23-30.

${ }^{35}$ J.A. Komenský, Wielka dydaktyka Jana Amosa Komeńskiego, s. 89. 
Repertuar tych błędów jest szeroki - nazywam ten zakres $9: 1$ - jedna odpowiedź jest prawidłowa, a dziewięć możliwych błędnych. Nauczyciel musi wiedzieć nie tylko, dlaczego odpowiedź jest błędna, ale jakie przesłanki lub sposoby rozumowania przywiodły ucznia do błędnej odpowiedzi. Na przykład, w fizyce nauczyciel musi mieć więc dobre przygotowanie nie tylko w zakresie dydaktyki, metodologii, ale też historii i filozofii nauki: Kartezjusz też sformułował trzy prawa dynamiki, ale pierwsze z nich (o inercji) było błędne; natomiast trzecie (o przekazie pędu) prostsze niż III prawo Newtona. $W$ innych naukach niezbędna jest podobnie szeroka wiedza interdyscyplinarna.

Badania ankietowe wśród nauczycieli w Wielkiej Brytanii wykazały, że nauczyciele boją się stosować kognitywistyczne metody nauczania, zdając sobie sprawę, że nie dysponują odpowiednim zakresem wiedzy, aby podejmować dyskusję „z wolnej ręki” z uczniami. Jednakże, jak stwierdza się w innym internetowym opracowaniu ${ }^{36}$, korzyści ze stosowania inquiry-based teaching są trudne do przecenienia: dokonuje się integracja wiedzy, umiejętności i koncepcji, umożliwiająca rozwiązywanie realnych problemów życia praktycznego $^{37}$. Do podobnych wniosków dochodzi Stanisław Dylak ${ }^{38}$ : o ile 99\% nauczycieli (i uczniów) uważa wyprzedzające strategie nauczania za interesujące, to zaledwie $7 \% \mathrm{z}$ nich deklaruje, że będzie je stosowało w praktyce szkolnej.

\section{Zasady dydaktyki hyper-kognitywistycznej}

Nowa dydaktyka definiuje w inny sposób „klasyczne” zasady dydaktyczne, jak zasada poglądowości, łączenia wiedzy z praktyką, stopniowania trudności, aktywnego udziału uczniów i tak dalej ${ }^{39}$. Nowe zasady nie zamieniają poprzednich, ale ich waga i wzajemne nachodzenie działań są inne. Główną stanowi aktywność grupowa uczniów, bez spetryfikowanego indywidualnego podziału ról: jest to połączenie zasady indywidualizacji nauczania (każdy uczeń ma możliwość wypowiedzenia własnej opinii, bez obawy przed negatywną oceną reszty grupy) z zasadą pracy grupowej (odpowiedzi, siłą rzeczy, są komplementarne).

${ }^{36}$ N.G. House, The Inquiry-based Approach to Teaching Math: Teaching Students to be Mathematical Thinkers, ISA (Institute for Student Achievements), 2018, https://www.studentachievement.org/blog/inquiry-based-approach-teaching-math-teaching-students-mathematical-thinkers/ [dostęp: 22.12.2018].

37 "The inquiry approach requires students to integrate knowledge, skills, and concepts and apply a body of knowledge to solve a real-life problem" (Tamże).

38 S. Dylak, "Nasze szkolne credo...", [w:] Strategia kształcenia wyprzedzającego, red. S. Dylak, Poznań 2013, s. 126.

${ }^{39}$ Zob. F. Bereźnicki, Dydaktyka kształcenia ogólnego. 
Komplementarność i spontaniczność wypowiedzi ma na celu budowanie samodzielności w zadawaniu pytań. W literaturze EU zasada ta nosi nazwę inquiry-based-teaching.

Podobnie podstawową zasadą jest usieciowanie wiedzy i praktyki uczeń musi wiedzieć, że wiedza jest potrzebna i to „zaraz, za rogiem”. Musi też kojarzyć - „miarka metrowa, zupełnie podobna do używanej przez mojego dziadka". Z punktu widzenia aksjologii, hyper-kontruktywizm, aktywizujący wszystkich uczniów, z ich uzdolnieniami komplementarnymi dla całości grupy, odpowiada zasadzie XXI wieku w polityce edukacyjnej USA i UE: no student left behind ${ }^{40}$.

Reasumując, przesłanki i procedury hyper-konstruktywizmu są następujące:

- Informacja jest wszech-dostęna.

- Nauczanie jest interaktywne.

- Suma indywidualnej wiedzy uczniów jest wyjściowym zasobem dla konstruowania wiedzy zbiorowej.

- Nauczyciel precyzyjnie definiuje (ale niekoniecznie w sposób jawny) cel lekcji (punkt dojścia w ścieżce interaktywnej) - prawo fizyczne, pojęcie, zjawisko.

- Zdefiniowany cel poznawczy nie jest jednak obiektem: to nasze wyobrażenie o tym obiekcie (kategoria pojęciowa, używając terminologii Kanta).

- Zadaniem nauczyciela nie jest przekazanie kategorii, ale jej wytworzenie w umyśle ucznia (uczeń czuje potrzebę używania nowej kategorii).

- Cel dojścia definiowany jest każdorazowo w nieco inny sposób, zgodnie z zasobami wiedzy grupy klasowej, warunków szkolnych (liczby godzin w programie, wyposażeniem pracowni itd.) - czyli zastanych zasobów kultury zbiorowej.

- Konstruując ścieżkę dojścia, nauczyciel korzysta z wiedzy uczniów, ale też z doświadczeń (w fizyce) lub zasobu faktów (w historii), tekstów (w języku polskim), „wyciąganych z kieszeni” ad hoc, dla właściwego ukierunkowywania toku dyskusji.

- Nauczanie jest demokratyczne, z poszanowaniem godności indywidualnych nauczyciela i ucznia.

- Nauczanie (i uczenie się) jest pełną radości procedurą odkrywania świata.

Ta ostatnia zasada pojawiła się już u Komeńskiego, który pisał, że jeśli nauczyciele będą wymowni i uprzejmi, a dzieci będziemy nagradzać jabłkami lub orzechami, ich pobyt w szkole będzie milszy niż w domu ${ }^{41}$. A serio, liczne

${ }^{40}$ G. Karwasz, A. Karbowski, No student left behind, s. 103-114.

41 "Jeśli nauczyciele będą wymowni i uprzejmi, a surowością nie będą odstręczali od siebie umysłu, lecz przeciwnie będą przywabiali do siebie przychylnością ojcowską, słowami i gestykulacją; jeśli nauki, jakie wykładają, zalecać będą z powodu ich doskonałości, przyjemności i ła- 
badania, w tym zagraniczne ${ }^{42}$, pokazują, że pierwsze lata szkolne są tym okresem, w którym uczniowie tracą swe początkowe zainteresowania poznawcze, niezależnie czy jest to fizyka czy język francuski.

Dekalog zasad dydaktyki demokratycznej, kognitywistycznej, efektywnej byłby następujący:

1. Zasada przeświadczenia (tak ucznia, jak i nauczyciela) o użyteczności wiedzy (dawna zasada łączenia teorii z praktyką).

2. Zasada wykorzystania talentów (dawna zasada indywidualizacji nauczania).

3. Zasada konstruowania (dawna zasada przystępności i stopniowania trudności).

4. Zasada superkompetencji nauczyciela (konieczność dostosowania nauczania do zmieniających się warunków i różnych potrzeb i/lub możliwości uczniów).

5. Zasada dojrzałości motywacyjnej tak ucznia, jak i nauczyciela („,po co ja to wszystko robię") - dawna zasada aktywizacji uczniów.

6. Zasada rozbudzania ciekawości poznawczej uczniów - u Komeńskiego „szkoła musi być miejscem, do której uczeń podąża z chęcią, jak na kolorowy jarmark" 43 .

7. Zasada interdyscyplinarności i wzajemnego usieciowania różnych sektorów wiedzy.

8. Zasada dialogu - między uczniami, między uczniami a nauczycielem, między nauczycielem a instytucjami edukacyjnymi - wynikająca z demokratyzacji kontaktów społecznych.

9. Zasada poszanowania różnorodnych możliwości poznawczych uczniów (no student left behind - zapewnienie wszystkim minimum wyników, ale bez identycznych wymagań w zakresie maksimum wiedzy).

10. Zasada poszanowania godności osobistej uczniów i nauczyciela (wynikająca z obowiązującego porządku prawnego i kultury współczesnego społeczeństwa).

twości; jeśli pilnych niekiedy będą chwalili (a pomiędzy mniejszych niekiedy rozdawali jabłka, orzechy, cukierki); jeśli ich do siebie przywołają i pokażą (albo u siebie albo podczas publicznéj nauki) ryciny tego, czego kiedyś mają się uczyć, obrazy, instrumenty optyczne albo jeometryczne, globusy i tym podobne rzeczy, które zdołają ich zadziwić; daléj, jeśli niekiedy będą uwiadamiali rodziców o ich postępach - jednym słowem, jeśli mile będą obchodzili się z dziećmi, to łatwo zdobędą sobie ich serca, tak dalece, że pobyt w szkole będzie im milszy niż w domu" (J.A. Komenský, Wielka dydaktyka Jana Amosa Komeńskiego, s. 102).

${ }^{42} \mathrm{~Np}$. J. Osborne, Attitudes towards science: a review of the literature and its implications, Int. J. Sci. Educ., 2003, 9(25), s. 1049-1079.

${ }^{43}$ J.A. Komenský, Wielka dydaktyka Jana Amosa Komeńskiego, s. 102. 
Szczególnie ważna jest zasada ostatnia - warunkiem efektywnego uczestnictwa całej grupy uczniowskiej (widzów, studentów) jest ich poczucie własnej wartości, co umożliwia swobodne wypowiadanie własnych poglądów. Wspomniany już Gerry House pisze ${ }^{44}$ :

Studenci stają się właścicielami swojego uczenia się. Moi studenci przewidują, interpretują, przedstawiają idee, bronią ich i dyskutują z nauczycielami, dlaczego przyjęli określoną metodę dla rozwiązania problemu. Ich głosy, myśli i idee są doceniane i respektowane $^{45}$.

Dwie metodologie - hyper-konstruktywizmu i realnych doświadczeń - są ściśle ze sobą związane: sam tylko dialog z widownią/klasą, ale bez interaktywnego, doświadczalnego odpowiadania na pytania, które się w tym dialogu pojawiają, dryfuje w kierunku pre-sokratesowych sofizmatów, aby nie powiedzieć umysłowych spekulacji (po włosku cavigli mentali, czyli meandrów umysłowych). Samo doświadczenie, bez przygotowania konstrukcji myślowej jest jeszcze bardziej szkodliwe. Pokazaliśmy „,cos", ale nie wiadomo po $\mathrm{co}^{46}$. Drugi raz ten sam eksperyment już ucznia nie zainteresuje: zmarnowany został eksponat, możliwość wytłumaczenia zjawiska, a co najgorzej - moment otwarcia umysłowego ucznia na nową wiedzę.

Nie jest nawet istotne, czy przewidywanie wyniku doświadczenia było poprawne czy nie: musi to przewidywanie mieć właściwe miejsce przed dokonaniem eksperymentu. Jak wykazują badania wśród studentów w USA ${ }^{47}$, jeżeli doświadczenie pokazano po przewidywaniu, ponad $80 \%$ udziela (następnego dnia) poprawnego wyjaśnienia zjawiska; jeśli doświadczenie przeprowadzono bez przewidywania, mniej niż $60 \%$ studentów udziela poprawnej odpowiedzi.

Niezwykle istotne jest też właściwe "kodowanie" słowne przekazu wie$\mathrm{dzy}^{48}$ : doświadczenia, nawet $\mathrm{w}$ fizyce, nie polegają na ich oglądaniu, ale na dyskutowaniu. Jak pisze Jeanne Ormrod ${ }^{49}$, ,język pozwala nie tylko na wzajemną komunikację, ale również na dekodowanie naszego doświadczenia

${ }^{44}$ G. House, The Inquiry-based Approach to Teaching Math.

45 "The students take ownership of their learning. My students predict, make inferences, pose ideas and defend them, and have discussions with their peers about why they used a certain process to solve a problem. Their voices, thoughts, and ideas are valued and respected" (Tamże).

${ }^{46}$ Cytując ponownie J.A. Komeńskiego (Wielka dydaktyka Jana Amosa Komeńskiego, s. 121): „II. Wszystko, co wykładamy, należy tak oprzeć na dostatecznych powodach, przyczynach (fundamentach), iżby stąd nie powstała żadna wątpliwość, ani nic nie przeszło w zapomnienie. Fundamenta (przyczyny) są jakoby owymi gwoździami, owymi wiązaniami, owymi klamrami, które utrzymują przedmiot i nie pozwalają mu się chwiać i upaść".

${ }^{47}$ K. Miller i in., Role of physics lecture demonstrations in conceptual learning, Phys. Rev. Special Topics, Physics Education Research, 2013, 9.

${ }^{48}$ G. Karwasz, Nauczanie fizyki.

${ }^{49}$ J.E. Ormrod, How We Think and Learn. Theoretical Perspectives and Practical Implications, New York 2017, s. 32. 
i na szybsze i efektywniejsze myślenie o nim". Oczywiście, w warunkach szybkich zmian edukacyjnych i kulturowych, "dekalog" powyższy musi być coraz to na nowo definiowany i interpretowany. Szczegółowe metodologie muszą być też dostosowywane do nauk szczegółowych - inne do chemii, inne do geografii, inne do fizyki ${ }^{50}$.

\section{Miscellanea}

Praktyczne implementacje dydaktyki hyper-konstruktywistycznej wymagają jeszcze kilku dodatkowych uwarunkowań.

\section{Trzy funkcje poznawcze}

Dydaktyka musi być ukierunkowana na niejednorodne grupy odbiorców. Innymi słowy, wykładowca/opis/eksponat musi zainteresować zarówno ucznia najsłabszego, jak i najlepiej przygotowanego oraz motywowanego. Dydaktyka musi być, parafrazując Komeńskiego, zabawowa, prosta, ale też intrygująca. W pracy Karwasz, Kruk ${ }^{51}$ zdefiniowano trzy funkcje poznawcze: 1) ludyczną, 2) dydaktyczną, 3) naukową. Po wykładzie, po zwiedzeniu interaktywnej wystawy, po samodzielnym eksperymentowaniu: 1) nawet najmniejszy widz musi powiedzieć ,jakie to fajne!, 2) nawet najsłabszy uczeń musi powiedzieć ,jakie to proste”, 3) a profesor uniwersytecki musi powiedzieć, „,nie wiedziałem, że to takie skomplikowane” ${ }^{25}$.

\section{Kompetencje społeczne}

To nie są jakieś wydumane "uczeń rozumie prawa Newtona”, ale to te aspekty dydaktyki, które będą przydatne „do końca życia”, jak na przykład, że droga hamowania zależy od stanu opon i szosy, ale dla danej prędkości nie będzie nigdy mniejsza niż...

W wykładzie o spadku swobodnym „Skok z kosmosu”, dla dzieci 6-10 lat, pokazujemy skok Felixa Baumgartnera na spadochronie ze stratosfery, ale wykład kończymy zrzuceniem z drabiny jajka na patelnię: „To będzie z wami, jeśli zeskoczycie z szafy". Niby zabawne, pełne emocji, ale zasadniczo istotne pedagogicznie.

\section{Emocje i poznanie}

Łączenie zabawy z nauką jest realizacją szerszej zasady - łączenia poznania z emocjami. W wykładach dla dzieci emocje są szczególnie istotne.

${ }^{50}$ Zob. np. G. Karwasz, Między Scylla a Charybda, czyli o Homerze i wulkanach, Geografia w Szkole, 2014, 2, s. 20-22.

${ }^{51}$ G. Karwasz, J. Kruk, Idee i realizacje dydaktyki interaktywnej.

${ }^{52}$ Zob. np. opisy „zabawek fizycznych”; tamże. 
Nieważne, czy ucznia zaskoczymy, zadziwimy, czy przestraszymy - nieoczekiwane wrażenia otwierają „kanał” poznawczy, a podkorowe emocje wzmacniają korowe, racjonalne poznanie. Dwóch funkcji nie sposób rozdzielić, jak stwierdza to Luiz Pessoa:

Już poprzednio przedstawiłem ideę, że emocje i poznanie nie mogą być rozgraniczone w mózgu, ponieważ „afektywne” obszary mózgu uczestniczą w poznaniu, z jednej strony, a „kognitywne” obszary mózgu uczestniczą w emocjach, z drugiej strony ${ }^{53}$.

W naszej koncepcji hyper-konstruktywistycznej nazywamy emocje „podkorowym wzmacnianiem funkcji poznawczych kory mózgowej".

\section{Ewaluacja dydaktyki hyper-konstruktywistycznej}

Jaka jest efektywność proponowanej dydaktyki? Pytanie jakby z zakresu mechaniki kwantowej: albo zbadamy tor elektronu, ale wówczas mechanika kwantowa nie zadziała, albo nie badamy toru i otrzymujemy piękny, kwantowy obraz interferencji elektronów. Klasyczna diagnostyka dydaktyczna wymaga grup kontrolnych i sprawdzenia wiedzy „na wejściu”. Ale zapowiedź, że lekcja będzie o grawitacji niszczy możliwość narracji, która powinna być zaskakująca: „To nie grawitacja jest powodem spadania ciał, ale ich naturalne miejsce w środku Ziemi, jak pisał Arystoteles. Prawda?" I dopiero takie postawienie pytania pozwala na rozpoczęcie ścieżki poznawczej, od jednego, do drugiego, doświadczalnego sprawdzania kolejnych hipotez.

Diagnostyka dydaktyki konstruktywistycznej jest więc bardzo trudna, możliwa w zasadzie jedynie ex-post. Jak piszą Alyssa Friend Wise i Kevin $\mathrm{O}^{\prime} \mathrm{Neill}^{54}$, cytując wcześniejsze prace:

nie ma sensu przeprowadzania klasycznych testów doświadczalnych nad uczeniem się innowacji, które to innowacje z natury rzeczy wymagają licznych jednoczesnych i współzależnych zmian w nauczaniu, aby stać się efektywne ${ }^{55}$.

Dydaktyka hyper-kognitywistyczna jest trudna, nie można więc oczekiwać, że stanie się kanonem nauczania, stąd jej zakwalifikowanie do „awangardy edukacji” ${ }^{156}$.

${ }^{53}$ L. Pessoa, The Cognitive-Emotional Brain: From Interactions to Integration, Cambridge, MA 2013, s. 3.

${ }^{54}$ A. Friend Wise, K. O'Neill, Beyond More Versus Less: A Reframing of the Debate on Instructions Guidance, [w]: Constructivistic Instruction; Success or Failure? red. S. Tobias, T.M. Duffy, New York - London 2009, s. 88.

55 “(...) it was meaningless to conduct a classical experimental trial of a learning innovation that, by its nature, requires a number of simultaneous and interdependent changes to instruction in order to be effective" (Tamże).

${ }^{56}$ G. Karwasz, Między neorealizmem a hyper-konstruktywizmem. 


\section{Konstruktywizm czy kognitywizm?}

Teoretyczne postawienie potrzeby nowej dydaktyki pojawiło się już w latach 30. ubiegłego wieku, szczególnie w pracach Jeana Piageta. Tradycyjna dydaktyka, kościelna (niezależnie od orientacji ${ }^{57}$ ), nie zajmowała się indywidualnością ucznia. W drugim "froncie” pedagogiki, w czasach rodzenia się pedagogii narodowych (Pestalozzi, Staszic, Herbart), problem indywidualności ucznia zaczyna się już pojawiać ${ }^{58}$. Jednakże, dopiero Piaget zaczyna śledzić, dzień po dniu, pojawianie się określonych umiejętności, inteligencji, jak on to nazywa, odruchowych lub świadomych u noworodków i niemowlaków. To pojawianie się inteligencji „dzień po dniu” przypomina konstruowanie ${ }^{59}$.

Jerome Bruner $\mathrm{w}$ kognitywizmie niejako wstępnie zakłada istnienie w umyśle człowieka określonych możliwości. W wielowątkowej dyskusji, między Naomem Chomskym a Piagetem w latach 70. XX wieku, ten pierwszy akcentował wrodzone predyspozycje językowe człowieka jako gatunku, ten drugi - proces konstruowania, choć zasadniczo nie ma sprzeczności w ich podejściu ${ }^{60}$. Oba kierunki - i kognitywizm, i konstruktywizm - czynią umyst ucznia centralnym elementem całego procesu uczenia się, a w zasadzie "terminowania" w społeczeństwie, jak czeladnik u majstra, czyli z angielskiego apprenticeship ${ }^{61}$.

${ }^{57}$ Jan Komeński, biskup Braci Czeskich (protestanckich kontynuatorów husytów), kończy Wielka dydaktykę Jana Amosa Komeńskiego stwierdzeniem: „to co napisałem, zrobiłem jako duchowny a nie jako pedagog".

${ }^{58}$ J.F. Herbart w 1806 roku pisał: „Wychowawcy, ogólnie rzecz biorąc, nie są ludźmi, którzy by posiadali najwięcej wiadomości. Są i tacy, którzy prawie nic nie umieją lub którzy swych wiadomości zupełnie nie umieją zastosować pedagogicznie, a mimo to przystępują do rzeczy z wielkim zapałem! Jakżeż tacy postępują? Przywłaszczają sobie władzę nad stroną uczuciową wychowanka, na tej nitce trzymają go i szarpią tak młodocianym umysłem, że ten wkrótce wychodzi z zawiasów. Jakże się tu może wytworzyć charakter? Charakter jest wewnętrzną niewzruszonością. Lecz jakże człowiek może wewnętrznie konsolidować się, skoro zabraniacie liczyć na cokolwiek? skoro mu nie pozwalacie wspierać się na jego własnej woli?

Najczęściej dzieje się tak, że w głębi młodocianej duszy pozostaje skrytka, do której nie potraficie wtargnąć i w której dusza, mimo waszego nękania żyje sama dla siebie, przeczuwa, roi, snuje plany, które stosuje przy pierwszej nadarzonej sposobności i które przy sprzyjających okolicznościach stworzą charakter właśnie tam, gdzie wyście nie mieli dostępu" (J.F. Herbart, Pedagogika ogólna wywiedziona z celu wychowania, Warszawa 1912, s. 16-18).

${ }_{59}$ "Umysł postępuje więc od czystej fenomenologii, której przejawy pozostają w połowie drogi między własnym ciałem a środowiskiem zewnętrznym, do aktywnego eksperymentowania, która jako jedyna wnika w istotę rzeczy. Co to oznacza, jeśli nie że dziecko nie odczuwa ze strony środowiska prostego naporu zewnętrznego, ale że próbuje się do niego dostosować? Doświadczenie nie jest więc pobieraniem, ale działaniem i postępującym po nim konstruowaniem: to jest fakt fundamentalny" (J. Piaget, La nascita dell'intelligenza del bambino, Milano 2014, s. 414, przekł. z włoskiego G.K.).

${ }^{60}$ M. Piattelli-Palmarini (red.), Język i jego nabywanie. Debata między Jeanem Piaagetem a Noamem Chomskym, przekł. A. Bielik-Robson, Warszawa 1995.

${ }^{61}$ B. Rogoff, Apprenticeship in Thinking Cognitive Development in Social Context, Oxford 1990. 
Jest oczywiste, że wrodzone zdolności są tylko pustymi strukturami i wymagają "zapełnienia półek”, ale konstruowanie musi korzystać z tych istniejących, wrodzonych możliwości, bo bez nich niczego się "czeladnik" nie nauczy. Dlatego, bazą teoretyczną obecnej dydaksji (używam terminu włoskiego na oznaczenie praktyki dydaktyki tak, jak pedagogia jest praktyką pedagogiki) jest zarówno konstruktywizm, jak i kognitywizm.

\section{Podsumowanie}

Dwie koncepcje hyper-konstruktywizm i neo-realizm wzajemnie się uzupełniają - wręcz nie mogą działać oddzielnie. Hyper-konstruktywizm, bez odwołania do realnej rzeczywistości, prowadzi do "meandrów" w interaktywnym grupowym procesie konstruowania wiedzy: realny obiekt, właściwe hasło $\mathrm{z}$ Wikipedii lub strona $\mathrm{w}$ drukowanym podręczniku historii natychmiast ukierunkowuje dyskusję na wytyczony cel. Eksponaty same w sobie, a szczególnie te "zabawowe”, prowadzą do pustej fenomenologii: stanowią przedwczesne zamknięcie możliwych zainteresowań poznawczych („a ja to już widziałem”, ,"a ja taką kulę plazmową mam”). Niestety, pokusą jest "pokazanie czegos", bo przynajmniej widz pozostaje (chwilowo) zajęty, a nie kognitywistyczne konstruowanie wiedzy w grupie zwiedzających i/lub klasie szkolnej: wiedzy na właściwym poziomie trudności i odpowiadającej adekwatnym do wieku potrzebom poznawczym uczniów, dzieci, dorosłych.

Proponowane strategie mają na celu wyposażenie odbiorców w umiejętności efektywnego wykorzystania zdobytej wiedzy, jak to określa Jerome Bruner, strategii podejmowania decyzji:

Określenie „strategie podejmowania decyzji” nie ma znaczenia metaforycznego. Strategia oznacza sposoby decyzji w przyswajaniu, przechowywaniu i wykorzystaniu informacji tak, aby służyła ona określonym celom, tzn. aby zabezpieczyć określony wynik i ochronić przed wynikami innego rodzaju ${ }^{62}$.

Era komputerów zmienia zasady dydaktyki: przybliża realizację celów z Didactica Magna Jana Komeńskiego: nauczania przyjemnego, trwałego i ekonomicznie efektywnego. Zresztą, jak pisał Jerome Bruner:

W każdym pokoleniu zachodzą zmiany - zarówno w warunkach życia, jak i w samej wiedzy - które z jednej strony ograniczają nauczyciela, z drugiej zaś - otwierają mu nowe możliwości działania ${ }^{63}$.

${ }^{62}$ J.S. Bruner, J.J. Goodnow, G.A. Austin, A Study of Thinking, s. 57.

${ }^{63}$ J.S. Bruner, W poszukiwaniu teorii nauczania, przekł. E. Krasińska, Warszawa 1974, s. 47. 
Niezwykle szybkie przemiany w dostępności informacji w XXI wieku wymagają jednak zupełnie nowego przygotowania nauczycieli (i struktur uniwersyteckich, które tych nauczycieli przygotowują).

Proponowane metodologie są jedynie częścią niezbędnych zmian, a ich praktyczna implementacja przyjmuje wiele form. Odnośnie dydaktyki kognitywistycznej Piero Crispiani pisze:

$\mathrm{W}$ towarzystwie refleksji wielu autorów działających w tym środowisku, rozwijamy poszukiwania teoretyczne usieciowań kognitywistycznych różnych koncepcji nauczania i problemów z nimi połączonych, mając świadomość, że dydaktyka kognitywistyczna nie jest metodą, nie opiera się na jednej procedurze czy jednym protokole, ale zbiera serię stwierdzeń i wątpliwości odnoszących się do jej obserwacji taką, jaką wydaje się ona dziś, do wiedzy wcześniejszej - od neuro-psychologii do pedagogiki, etologii, socjologii, etc., razem - do najbardziej wiarygodnego przejawu działania myśli, a więc do umysłu człowieka ${ }^{64}$.

Wymagane zmiany to już nie tylko konstruowanie wiedzy czy inteligencji, to już nie poszukiwania interpretacji zaistniałych treści w umyśle odbiorcy: współcześnie, w XXI wieku to konieczność przygotowania struktur umysłowych dla przyjęcia myślenia - podstaw logiki, matematyki, a także aksjologii. Głowa nie ma być wypełniona wiadomościami, ale dobrze skonstruowana, aby w trakcie uczenia się (przez całe życie) zapełniać gotowe (ale jeszcze puste) przegrody odpowiednimi kompetencjami. Jak pisze Edgar Morin ${ }^{65}$, pilnej reformy wymaga nie tylko system szkolny, ale cały sposób społecznego myślenia.

Kończymy cytatem z książki Zbigniewa Pietrasińskiego, z 1975 roku: „Myślenie jest zarówno warunkiem efektywnego uczenia się, jak i jego szczególnie istotnym wynikiem". Zarówno konstruktywizm, jak i kognitywizm narodziły się w wieku XX, ale może w XXI wieku doczekają się powszechniejszego stosowania w praktyce dydaktycznej i pedagogicznej ${ }^{66}$.

\section{BIBLIOGRAFIA}

Astolfi J.-P., L'erreur, un outil pour enseigner. Pratiques et enjeux pédagogiques, ESF Science Humaines, Montrouge 2012.

Bereźnicki F., Dydaktyka kształcenia ogólnego, Oficyna Wydawnicza Impuls, Kraków 2007. Berger P.L., Luckmann T., Społeczne tworzenie rzeczywistości, przekł. J. Niżnik, Wydawnictwo Naukowe PWN, Warszawa 2010.

${ }^{64}$ P. Crispiani, Didattica Cognitivista, Roma 2004, s. 13.

${ }^{65}$ E. Morin, La tête bien faite, Paris 1999.

${ }^{66}$ G. Karwasz, K. Służewski, A. Kamińska, Constructivistic path in teaching physics: from interactive experiements to step-by-step textbooks, Problems of Education in the 21st Century, 2015, 64, s. 6-23. 
Brojan J., Sawicki S., Sapanowski S., Sprawozdanie z egzaminu maturalnego 2014. Fizyka i astronomia, Centralna Komisja Egzaminacyjna, Warszawa 2014.

Bruner J.S., W poszukiwaniu teorii nauczania, przekł. E. Krasińska, Państwowy Instytut Wydawniczy, Warszawa 1974.

Bruner J.S., Goodnow J.J., Austin G.A., A Study of Thinking, Transaction Publishers, New Brunswick - New York 1986.

Crispiani P., Didattica Cognitivista, Armando Editore, Roma 2004.

Crispiani P., Dydaktyka, edukacja, styl. Dydaktyka kognitywistyczna jako styl, przekł. G. Karwasz, Cognitive Science - New Media - Education, 2017, 3.

Ćwikliński A., Zmiany w polskiej edukacji w okresie globalizacji, integracji i transformacji systemowej, Wydawnictwo Naukowe UAM, Poznań 2005.

Dylak S., „Nasze szkolne credo...”, [w:] Strategia kształcenia wyprzedzajacego, red. S. Dylak, Wydawnictwo Naukowe UAM, Poznań 2013.

Friend Wise A., O'Neill K., Beyond More Versus Less: A Reframing of the Debate on Instructions Guidance, $[w]$ : Constructivistic Instruction; Success or Failure? red. S. Tobias, T.M. Duffy, Routledge, Taylor \& Francis Group, New York - London 2009.

Gagnon Jr. G.W., Collay M., Constructivistic Learning Design. Key Questions for Teaching to Standards, Corwin Press, Thousand Oaks, California 2006.

Hazelkorn E. (chair), Science Education for Responsible Citizenship, Report to the European Commission of the Expert Group on Science Education, European Commission, Luxembourg 2015.

Herbart J.F., Pedagogika ogólna wywiedziona z celu wychowania, Geberther i Wolff, Warszawa 1912.

House N.G., The Inquiry-based Approach to Teaching Math: Teaching Students to be Mathematical Thinkers, ISA (Institute for Student Achievements), 2018, https://www.studentachievement.org/blog/inquiry-based-approach-teaching-math-teaching-students-mathematical-thinkers/ [dostęp: 22.12.2018].

Karwasz G., Czy świat kręci się w prawo? Fizyka i zabawki, XXXV Zjazd Fizyków Polskich, 20.09.1999 Białystok, Postępy Fizyki, 2000, 51, Zeszyt dodatkowy.

Karwasz G., Czy media w dydaktyce sa potrzebne? [w]: Media w edukacji, kulturze i zmianie społecznej - odniesienia kognitywne, Księga jubileuszowa poświęcona profesorowi Bronisławowi Siemienieckiemu w 60. rocznicę urodzin, red. S. Juszczyk, Wydawnictwo Adam Marszałek, Torun 2010.

Karwasz G., Między neorealizmem a hyper-konstruktywizmem - strategie dydaktyczne dla XXI wieku, [w]: Awangarda w szkolnej i pozaszkolnej edukacji, Problemy Wczesnej Edukacji, 2011, 3(15).

Karwasz G., Nauczanie fizyki - trudności matematyczne czy nieumiejętność komunikacji? Kognitywistyka i Media w Edukacji, 2013, 1.

Karwasz G., Teaching science in early childhood - inquiry-based, interactive path on energy, [w]: Physics Alive, Proceedings GIREP-EPEC Conference, JYFL Research Report no.10/2012, red. A. Lindell, A-L. Kähkönen, J. Viiri, University of Jyväskylä.

Karwasz G., Między Scylla a Charybda, czyli o Homerze i wulkanach, Geografia w Szkole, 2014, 2.

Karwasz G., Didattica cognitivista come ricetta in fisica, [w]: Le vie della pedagogia. Tra linguagi, ambiente e tecnologie, a cura di P. Crispiani e S. Pellegrini, Edizioni Università di Macerata, 2016.

Karwasz G., Kruk J., Idee i realizacje dydaktyki interaktywnej. Wystawy, muzea i centra nauki, Wydawnictwo Naukowe Uniwersytetu Mikołaja Kopernika, Torun 2012. 
Karwasz G., Karbowski A., No student left behind - recepta konstruktywistyczna - implementacje i analizy porównawcze w fizyce, [w:] Różnice, edukacja, inkluzja, red. A. Komorowska, Wydawnictwo Naukowe Uniwersytetu Gdańskiego, Gdańsk 2015.

Karwasz G., Służewski K., Kamińska A., Constructivistic path in teaching physics: from interactive experiements to step-by-step textbooks, Problems of Education in the 21st Century, 2015,64 .

Karwasz G., Karbowski A., Hyper-konstruktywizm w nauczaniu fizyki. Tożsamość indywidualna i kompetencje społeczne, Acta Universitatis Nicolai Copernici. Pedagogika, 2016, XXXII, Nauki Humanistyczno-Społeczne, 435.

Kirschner P.A., Sweller J., Clark R.E., Why Mimimal Guidance During Instruction Does Not Work: An Analysis of the Failure of Cnstructivistic, Discovery, Problem-Bases, Experiential, and Inquiry-Based Teaching, Educational Psychologists, 2006, 41(2).

Komenský J.A., Wielka dydaktyka Jana Amosa Komeńskiego, przekł. H. Wernic, Nakładem Redakcyj Przeglądu Pedagogicznego, Warszawa 1883.

Kruk J., Karwasz G., Reprezentacja, przyczynowość i badania eksperymentalne jako znaczące punkty "mapy poznawczej” dydaktyki ogólnej, Forum Oświatowe, 2005, 2(33).

Miller K., Lasry N., Chu K., Mazur E., Role of physics lecture demonstrations in conceptual learning, Phys. Rev. Special Topics, Physics Education Research, 2013, 9.

Morin E., La tête bien faite, Seuil, Paris 1999.

Ormrod J.E., How We Think and Learn. Theoretical Perspectives and Practical Implications, Cambridge University Press, New York 2017.

Osborne J., Attitudes towards science: a review of the literature and its implications, Int. J. Sci. Educ., 2003, 9(25).

Pacholik-Żuromska A., Ewolucja języka myśli, Diametros, 2012, 34.

Pessoa L., The Cognitive-Emotional Brain: From Interactions to Integration, MIT Press, Cambridge, MA 2013.

Piaget J., La nascita dell'intelligenza del bambino, Milano 2014.

Piattelli-Palmarini M. (red.), Język i jego nabywanie. Debata między Jeanem Piaagetem a Noamem Chomskym, przekł. A. Bielik-Robson, Wydawnictwo IFiS PAN, Warszawa 1995.

Pietrasiński Z., Sztuka uczenia się, Wiedza Powszechna, Warszawa 1975.

Rogoff B., Apprenticeship in Thinking Cognitive Development in Social Context, Oxford University Press, Oxford 1990.

Shulman L.M., Knowledge and teaching: Foundations of the new reform, Harvard Educational Review, 1987, 57(1).

Siemieniecka D., Karwasz G., Internetowa tożsamość - czyli o kreowaniu własnego ID, [w]: Oblicza internetu. Sieciowe dyskursy. (Roz)poznawanie cyfrowego świata, red. M. Sokołowski, Państwowa Wyższa Szkoła Zawodowa w Elblągu, Elbląg 2014.

Siemieniecki B., Pedagogika kognitywistyczna. Studium teoretyczne, Oficyna Wydawnicza Impuls, Kraków 2013.

Smerdon B. i in., Teachers' Tools for the 21st Century: A Report on Teachers' Use of Technology, National Center for Education Statistics, U.S. Department for Educations, NCES2000102, September 2000.

Zanetti V. i in., I giocattoli e la scienza - schede per una diversa didattica della fisica, "La fisica nella scuola" (A.I.F.) quaderno n.4 - ottobre/dicembre 1993. 